\title{
For the Sake of the Cause - Persistence of Romanian Higher Education Students in Finishing their Studies
}

\author{
Emese Berei ${ }^{1}$ \\ Recommended citation: \\ Berei, E. (2019). For the Sake of the Cause - Persistence of Romanian Higher Education Students in Finishing \\ their Studies. Central European Journal of Educational Research, 1(1), 22 - 30.
}

\begin{abstract}
As a consequence of the expansion in higher education, the number of students has increased and the academic population has diversified but at the same time the university dropout has become a general problem since the last century (Trow, 2005; Kozma, 2010; Barro \& Jong, 2013; Stanciu, 2014; Berei, 2018). In this paper, I proposed to analyze the persistence of students from 5 universities from Romania. We examine at institutional and individual level the perspective of their willingness to finish their studies. In partnership with the Center for Higher Education Research and Development - Hungary, named CHERD - $\mathrm{H}$, from the University of Debrecen, was collected dates among students in 2012 ( $\mathrm{N}=1323)$ and in $2014-2015(\mathrm{~N}=323)$. Through a quantitative analysis, on a longitudinal perspective, I used SPSS statistical program to analyze data. The question of the research was: is there any difference between students' intentions to graduate on private and state institutions? Who is intending to finish and who is preparing to abandon his study? I concluded that students with unfavorable family background have nearly two times lower chance to enroll at state university and in private institutions students intention to enter into possesion of diploma was significant lower. With logistic regression I found also, that low financial status or low schooling of parents is not a significant obstacle on student academic path if they make every effort to participate in educational programs, submit assignments on time and are able to prepare for exams.
\end{abstract}

Keywords: higher education students 1; private and state institutions 2; persistence 3 Romania4

\section{Introduction}

In Europe, the first universities were founded in 11-12 centuries and they had the prime role in the society to prepare the "elite". The population of students in higher education was homogenous and less than $10 \%$ of the young generation continue to learn in universities, in all countries (Trow, 2005; Polónyi, 2008).

The massification process at tertiary level started in Europe after the II. World War due to social and economic changes (Kozma, 2010). The population become quickly diverse and the number of students has multiplied but the university leaving rates increased also (Barro \& Jong, 2013). In this paper I proposed to analyze the Romanian situation, focusing on students' persistence.

Romania is a post-communist country, with 20.1 million people (INS 2013). Before 1989, the national higher education system was strictly regulated by the state. After the democratic changes in 1989, due to new educational reforms, statistical data reflect the shift from "elite" to "mass" higher education population, but the system was not prepared from the point of view of social equity (equality and supporting practices), to integrate the non-traditional groups (with low-income family background, living with disabilities, from marginalized living area background and Roma students) in academic world (Berei, 2018a).

\footnotetext{
${ }^{1}$ Emanuel University from Oradea, Romania; emese.berei@emanuel.ro
} 
According to the students' opinions, after 1989 was no educational policy priority for any Romanian government the improvement of the social and economic background of students (ESIB, 2007).

The first changes were seen in the increasing number of institutions. While in 1990 the Romanian state had 48 higher education institutions, in 2000 this number increased by 2,5 times ( 58 state and 63 private universities were registered) (Curaj et al., 2015). In 2010, a total of 109 higher education institutions prepared students at the tertiary level. Twenty percent of this was historical institutions with more than a hundred years old, while half of the Romanian higher education institutions were younger than twenty years. In that period, the number of students quadrupled also (Stanciu, 2014).

Especially in the private institutions have been launched new programs, mainly human and social sciences. In 2006 the Bologna system with three levels was introduced in Romanian higher education. The student/teacher ratio has doubled, but the curriculum has not been renewed. The number of students growing until 2009, but several non-traditional groups remain underrepresented in the higher education system (Curaj et al., 2013).

After the economic crisis, the European Student Union (ESU) considered the inclusiveness of higher education as a cornerstone of the Bologna Process. As a result of there work, since 2007 the EUROSTUDENT surveys explore the social and economic conditions of Romanian students' lives (called the social dimension of the education). Romanian students identified the wrong choice of career as the primary reason for dropouts, the second being the financial situation of students (ANASOR, 2012).

At the international level, ESU researchers studied the issue of dropout and study delay in EU countries. More than half of the countries have educational policy regulations in this area, but only Denmark, Austria, Finland, the UK, and Norway have made this data available until 2012 (ESU, 2012).

Nowadays, the "gravitational center" of the education has been transferred to higher education, so it is important for governments to do much more to prevent dropout and support successful student studies. In particular, there are three areas for reform: „remedial education”, „student support service" and "financial aid" (Polónyi, 2008; Brock, 2010).

The universities included in this study is private and state higher educational institutions integrated into the national education system, under the authority of the Ministry of National Education, accredited by the Romanian Agency for Quality Assurance in Higher Education (ARACIS). Monitoring the graduation rate in all specialization fields is a requirement since 2014 towards the Romanian universities, it confirms the effectiveness of the teaching-learning process and at the same time the persistence of the students in finishing their study.

In Romania, the rate of full-time students enrolled in three consecutive academic years was about $90 \%$ in the BA cycle. The other $10 \%$ was enrolled in part-time programs.

In private institutions the rate of students was 16\% (in 2014-2015), $14.4 \%$ (in 2015-2016), $13.5 \%$ (in 2016-2017) and 13.7\% (in 2017-2018), comparing with the rate of the students enrolled in state institutions (Figure 1.). During these consecutive years, the total number of students dropped out was 5591. 


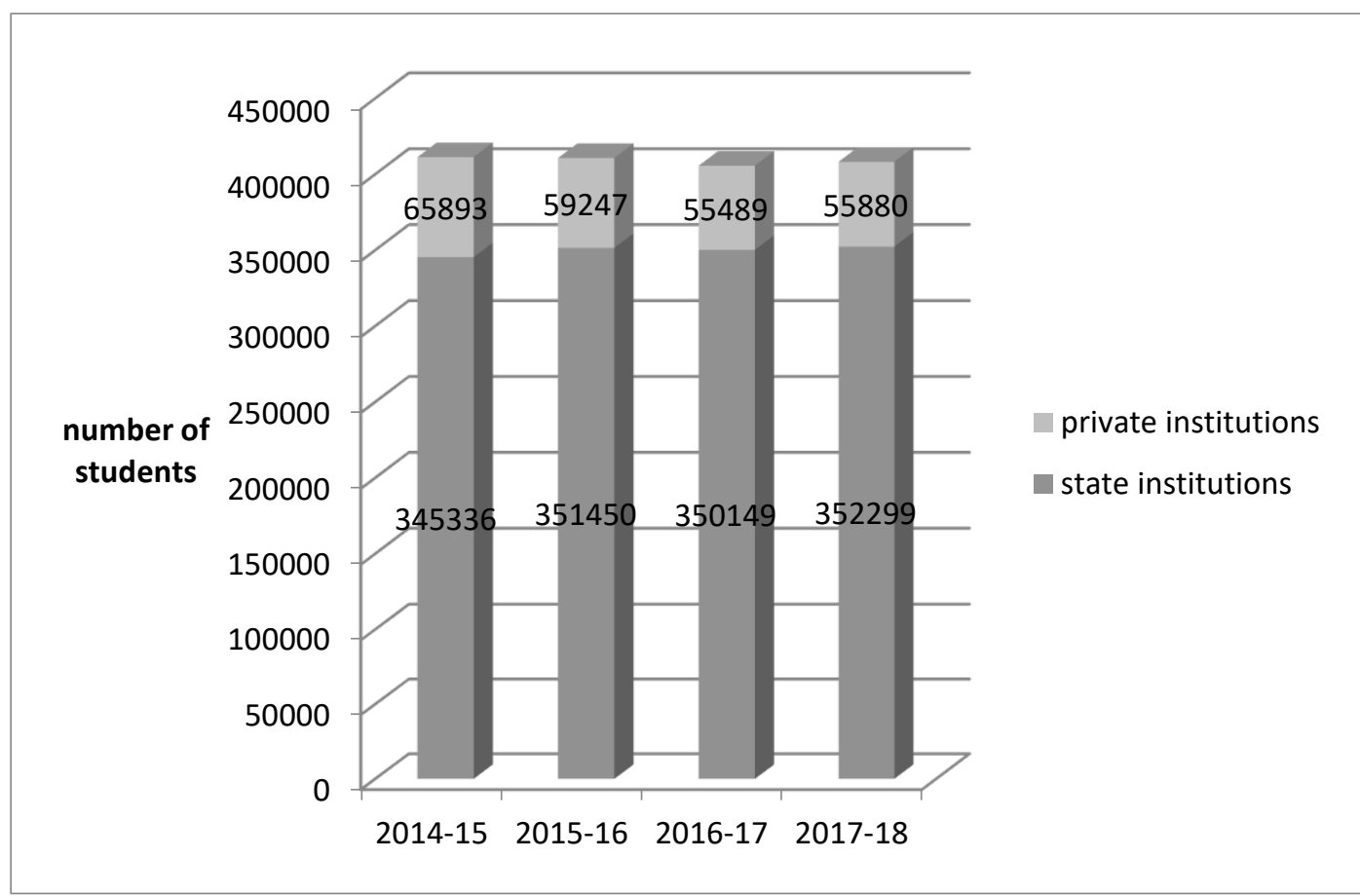

Figure 1. Number of BA students in state and private institutions (N)

Source: Ministerul Educatiei Nationale. Raport privind starea invatamantului superior din Romania 2017-2018.

Regarding at the rate of the graduation, we have country-level statistical data starting from the academic year 2014 - 2015 (Table 1). The persistence of BA students was between 82-85\% per country. The persistence of students from the full-time programs and from the state universities was the most higher. The rate of those who lost during the academic years was below $10 \%$. This number has risen to $15-17 \%$ if we take into account the number of those who have repeated the year or have not completed their school situation. Statistical data revealed to us that, in private universities the rate of graduation each year was lower than in the state institutions. In this paper, I also search an answer to this question: is this graduation gap between state and private universities?

Table 1. Rate of the persistence students in Romanian universities (\%)

\begin{tabular}{|c|c|c|c|}
\hline \multicolumn{4}{|c|}{ Academic year $2014-2015$} \\
\hline & $\begin{array}{l}\text { Rate of the } \\
\text { promovability }\end{array}$ & $\begin{array}{l}\text { Rate of the repetition or } \\
\text { non complet situations }\end{array}$ & $\begin{array}{l}\text { Rate of } \\
\text { dropout }\end{array}$ \\
\hline State & 85.3 & 5.9 & 8.7 \\
\hline Private & 82.8 & 9.9 & 7.3 \\
\hline \multicolumn{4}{|c|}{ Academic year 2015 - 2016} \\
\hline State & 84.8 & 6.1 & 9.1 \\
\hline Private & 83.3 & 10.3 & 6.4 \\
\hline \multicolumn{4}{|c|}{ Academic year 2016 - 2017} \\
\hline State & 84.9 & 5.8 & 9.3 \\
\hline Private & 84.0 & 6.7 & 9.2 \\
\hline
\end{tabular}

Source: Ministerul Educatiei Nationale. Raport privind starea invatamantului superior din Romania 2017-2018.

At individual level, persistence is one of the dimensions of student effectiveness and educational success (Pusztai, 2015). When Tinto (1993) created a complex model of dropping out, he took a holistic account of the student's history (individual qualities, abilities, family background and prior education), academic embedding (goals, interactions and integration in the higher education institution) and the social integration (on formal and non-formal environments). The lack of commitment to achieving the educational goal leads to dropout from higher education studies (abandon). In my study, I proceded from the standpoint that dropout is a process, I assumed that the 
final decision to abandon is preceeded by smaller steps: students do not participate in educational programs (courses, seminaries), are not able to prepare for exams, are not on time to submits assignments.

\section{Research design and Methods}

The general purpose of my research was to analyze the persistence of Romanian students at institutional and individual levels. In this paper I will examine this topic from the perspective of the output, comparing state and private institutions 'students' persistence, their educational intention concerning finishing academic study ${ }^{2}$. The question of the research was: is there a difference between private and state institution 'students on their intentions to graduate? Who is able to finish and who is preparing to abandon his study?

The quantitative international survey data used in my analysis was collected and made available by the Center for Higher Education Research and Development - Hungary at the University of Debrecen, in 2012 ( $\mathrm{N}=2618$ ) and 2014-15 ( $=1300)$ by HERD (Higher Education for Social Cohesion Cooperative Research) and IESA (Institutional Effects on Student Achievements in Higher Education) projects, conducted in countries of Central and Eastern Europe (Hungary, Romania, Ukraine, Slovakia and Serbia). The conceptions of the research projects and the characteristics of the sample were described on Pusztai at al. (2012) and Pusztai at al. (2016).

In this paper I had focused on the subsample from Romania, conducting in 5 higher education institutions (Table 2.). In cross-border area, from Oradea, it was included one state university and two private institutions: Partium Christian University and Emanuel University. On other part of Romania, the Babes-Bolyai University from Cluj, with his branch in Satu-Mare and Odorheiu Secuiesc and Sapientia University of Transylvania from Cluj, Tg.-Mures and Miercurea-Ciuc, cooperate with CHERD-H, to conduct the research among students.

Table 2. State and private universities with the number of students, included in sample $(\mathrm{N})$

\begin{tabular}{ccc}
\hline Institutions (city, founded at) & HERD 2012 & IESA 2014-15 \\
\hline University of Oradea (Oradea, state) & 714 & 15 \\
Partium Christian University (Oradea, private) & 407 & 40 \\
Emanuel University (Oradea, private) & 136 & - \\
Babes - Bolyai University (Cluj/Satu Mare/ & 66 & 138 \\
Odorheiu Secuiesc, state) & & 126 \\
Sapientia University of Transylvania (Cluj/Tg & - & $\mathbf{3 2 3}$ \\
Mures/Miercurea Ciuc, private) & & $\mathbf{1 3 2 3}$ \\
Totally number of students &
\end{tabular}

To present the respondents` demographic and social characteristics ${ }^{3}$, I used variable to explore their gender and place of residence at age of 14 respectively family backgrounds: mother's and father's level of education and subjective financial status'. I considered disadvantaged student who's subjective financial status was lower than the average.

Concerning students' academic characteristics, it was included mostly full-time BA level students at entered years ( 1 or 2 ). More than half of students were enrolled at state universities, the other part included on the sample was from private institutions ${ }^{5}$.

\footnotetext{
2 I am very intent on finishing my studies.

4 - fully agree 3 - agree 2 - not agree 1 - certain not agree 9 - I don't now

3 The data are included in the appendix, in table number 5

${ }^{4}$ Concerning students appreciation, measured on a 1-10 scale

5 The data are included in the appendix, in table number 6
} 
Through a quantitative analysis, on a longitudinal perspective, I used SPSS statistical program to analyze data.

\section{Results}

\subsection{Persistence on state and private institutions: why is it difference?}

On Hungarian - Romanian border region Hatos (2012) studied the recruiting policy of private and state universities and he called attention on the selective nature of state institutions. His conclusion was that in Oradea students from disadvantaged family background mostly study in private universities (Emanuel Univesity and Partium Christian University). On my earlier research, I concluded that the dropout is a serious risk to the disadvantaged family background students on Hungarian cross border universities and not just their family socialization models are damaged (Bourdieu, 1978; Boudon, 1981; Brock, 2010) but also their individual behavior: they do not fully participate in the classes and their commitment is not satisfactory (Berei, 2018b). For these reasons firstly I suppose in my present examination, that students from the private institutions are significantly less able to finish their study, than students who are enrolled at state universities.

With Chi-square test statistic examination I concluded, that student with low financial family status was significantly more concentrated on private institutions and students intention on finishing their studies on private institutions were statistically lower than in-state universities. Comparing in cross-border area the financial family background of Romanian students from state and private institutions, I concluded that students with favorable family background have 2 times better chance to enroll at a state university and on the same time their chance to enter into possession of diploma was 2 times better (OR=2.2) (Table 3).

Table 3. The students financial backgroung and their academic intentions at state and private institutions (\%)

\begin{tabular}{cccccc}
\hline & state & private & $\begin{array}{c}\text { Pearson } \\
\text { Chi-square }\end{array}$ & $\begin{array}{c}\text { Odds } \\
\text { ratio }\end{array}$ & $\mathbf{N}$ \\
\hline $\begin{array}{c}\text { Low subjective financial situation of the } \\
\text { family }\end{array}$ & 11 & $\underline{\mathbf{1 6}}^{* *}$ & 0.011 & 0.651 & 1257 \\
$\begin{array}{c}\text { Intent on finishing studies } \\
\text { f2 }\end{array}$ & $\underline{\mathbf{2}}^{* * *}$ & 84 & 0.000 & 2.2 & 1247 \\
\hline
\end{tabular}

The underlined figures indicate that the percentage in the given cell is higher than expected in a random distribution. Level of significance: ${ }^{* * *} \mathrm{p}<0.001,{ }^{* *} \mathrm{p}<0.01$. Source: HERD 2012 (subsample of Romania)

\subsection{What persistent students enduring for the sake of the cause?}

To characterize the persistence at the individual level, I used the Pusztai (2015) model. Persistence of students means their intention of finishing higher education study. At the same time, I assumed that this is not independent of the other dimensions - persistence with the aim of the studies is related to engagement on study and with the morality of working (integrity). The intention to get the academic diploma is connected with the commitment to learning and with the quality of the study. I have examined both databases with Chi-square test and my conclusion was: those students are significantly persistent in obtaining a diploma who makes every effort to participate in educational programs, submits assignments on time, are able to prepare for exams and are able to spend time studying instead of doing more interesting things. Odds ratio show that the chance on finishing the study was 4-7 times lower if students do not participate at educational programs (courses, seminaries), are not able to prepare for exams, are not on time to submits assignments ${ }^{6}$.

Finally, I checked with logistic regression how the effectiveness indicators affect students' intentions to finish their studies, alongside demographic and social background factors. I concluded that low financial situation or low schooling of parents is not a significant obstacles on student

\footnotetext{
${ }^{6}$ In the appendix, in table numbers 7 and 8
} 
academic path if they make every effort to be able to participate in courses submit assignments on time and is able to prepare for exams. Students who make every effort to be able to participate in educational programmes submit assignments on time and are able to prepare for exams had 2-4 times higher chance of finishing the study.

Table 4. Persistent student chance controlled by the variable of social background

\begin{tabular}{|c|c|c|}
\hline & \multicolumn{2}{|c|}{ Dependent variable: Intent of finishing studies } \\
\hline & $\begin{array}{c}\operatorname{Exp}(B) \\
\text { (HERD 2012) }\end{array}$ & $\begin{array}{c}\text { Exp (B) } \\
\text { (IESA 2014-2015) }\end{array}$ \\
\hline Submits assignments on time & $2.730^{* * *}$ & $2.88^{* *}$ \\
\hline $\begin{array}{c}\text { Makes every effort to be able to } \\
\text { participate in courses }\end{array}$ & $2.456^{* * *}$ & $4.25^{* * *}$ \\
\hline $\begin{array}{l}\text { Able to spend time studying instead of } \\
\text { doing more interesting things }\end{array}$ & 1.183 & 1.33 \\
\hline Able to prepare for exams & $2.436^{* * *}$ & 0.94 \\
\hline Father's level of education & 1.015 & 0.675 \\
\hline Mother's level of education & 0.700 & 1.622 \\
\hline Gender & 0.809 & 1.179 \\
\hline Place of residence at the age of 14 & 0.937 & 0.804 \\
\hline $\begin{array}{l}\text { Subjective financial situation of the } \\
\text { family }\end{array}$ & 1.056 & 0.461 \\
\hline
\end{tabular}

\section{Discussion}

On the strength of these results, I concluded that my first hypothesis was admitted: students from private institutions have a significant 2 times higher chance to dropout from their study than students who are enrolled at state universities.

My second hypothesis was, that the intention of students to get the academic diploma is connected with the commitment to learning and with the quality of the study: students make effort to participate in courses, are able to spend time studying instead of doing more interesting things, submits assignments on time and are able to prepare for exams. Chi-square tests confirm this hypothesis and Odds ratio show that the chance on finishing study was 4-7 times lower if students do not participate in educational programs (courses, seminaries), are not able to prepare for exams, are not on time to submits assignments. I concluded also that low financial situation or low schooling of parents is not significant obstacles on student academic path if they make effort to participate in courses, submits assignments on time and are able to prepare for exams.

\section{Conclusions}

My intention was to analyze the persistence of students at an institutional and individual level, from the perspective of the output, comparing state and private institutions' students' persistence and their individual intention concerning finishing the academic study. Our earlier research on cross border region (Hatos, 2012; Berei, 2018b) confirm, that students with the disadvantaged family backgrounds are disadvantaged also on finishing their study and they are concentrated at private higher education institutions. Statistical numbers show and my examination confirm also, that students from private institutions had a lower rate of persistence in private institutions than in-state universities. Concerning the general financial situation of private higher education Romanian institutions, they get no financial support from the state in the despite the high number of disadvantaged family background students. My suggestion is, that institutions should be divided not just in state and private categories, but dependent on the number of disadvantaged students, enrolled 
in higher education. In material financing of the institutions this aspect should also be considered. Private institutions with a high number of disadvantaged students would be good to have financial state support and I recommend for institutions to have a strategy in motivating and supporting the persistence of disadvantaged students.

In my present quantitative examination I demonstrate also, that disadvantaged family background has no a significant negative effect on students' persistence to finishing their studies. The individual effort to participate in educational programs, to submits assignments on time and to be able to prepare for exams, increase 2-4 times their chance to persist and finish the study.

Funding: "This research received no external funding"

Conflicts of Interest: “The authors declare no conflict of interest."

\section{Appendix}

Table 5. Respondents' demographic and social characteristics (\%)

\begin{tabular}{cccc}
\hline & & HERD 2012 & IESA 2014-15 \\
& & & \\
\hline \multirow{3}{*}{ Gender } & Male & 37.3 & 16.4 \\
& Female & 62.7 & 83.6 \\
& Totally & 100 & 100 \\
Place of residence at & Rural & 33.1 & 46.7 \\
the age of 14 & Urban & 67 & 53.4 \\
& Totally & 100 & 100 \\
Mother's level of & Low & 29 & 30.6 \\
education & Middle & 48.6 & 51.8 \\
& High & 22,3 & 28.7 \\
& Totally & 100 & 100 \\
Father's level of & Low & 28.8 & 37.2 \\
education & Middle & 49.7 & 47.2 \\
& High & 21.3 & 22 \\
Subjective financial & Totally & 100 & 100 \\
situation of the & Low (1-4) & 12.4 & 22.9 \\
family & Middle or high (5-10) & 87.6 & 77.1 \\
$\mathbf{N}$ & Totally & 100 & 100 \\
& & $\mathbf{1 3 2 3}$ & $\mathbf{3 2 3}$ \\
\hline
\end{tabular}

Table 6. Respondents' academic characteristics (\%)

\begin{tabular}{cccc}
\hline & & HERD & IESA \\
& & $\mathbf{2 0 1 2}$ & $\mathbf{2 0 1 4 - 1 5}$ \\
\hline \multirow{3}{*}{ Cyrcle of the study } & BA & 89.1 & 92.1 \\
& MA & 10.9 & 7.9 \\
& Totally & 100 & 100 \\
Year of the study & Just entered (1-2) & 69.2 & 81.8 \\
& Close to graduation (3-6) & 30.8 & 18.2 \\
Financed & Totally & 100 & 100 \\
& By the state & 57 & 74.4 \\
& Fee cost & 43 & 25.6 \\
& Totally & 100 & 100 \\
\hline
\end{tabular}




\begin{tabular}{cccc}
\hline \multirow{3}{*}{ Type of the study } & Full-time & 99.7 & 98.5 \\
& Part time & 0.3 & 1.5 \\
& Totally & 100 & 100 \\
Type of the higher & State & 58.9 & 51.4 \\
education institutions & Private & 41 & 48.6 \\
& Totally & 100 & 100 \\
\hline
\end{tabular}

Table 7. Academic involvement of students and their intention on finishing the study (\%)

\begin{tabular}{|c|c|c|c|c|c|}
\hline & & $\begin{array}{l}\text { Intention } \\
(\%)\end{array}$ & $\begin{array}{c}\text { Pearson } \\
\text { Chi-square }\end{array}$ & $\begin{array}{l}\text { Odds } \\
\text { ratio }\end{array}$ & $\mathbf{N}$ \\
\hline $\begin{array}{l}\text { Able to spend time studying instead of } \\
\text { doing more interesting things }\end{array}$ & $\begin{array}{l}\text { 1. yes } \\
0 . \text { no }\end{array}$ & $\underline{92.6}_{81.6}^{* * *}$ & 0.000 & 2.8 & 1309 \\
\hline Submits assignments in time & $\begin{array}{l}\text { 1. yes } \\
0 . \text { no }\end{array}$ & ${\underline{93.3^{* * *}}}_{68.1}$ & 0.000 & 6.6 & 1305 \\
\hline $\begin{array}{l}\text { Makes every effort to be able to } \\
\text { participate in courses }\end{array}$ & $\begin{array}{l}\text { 1. yes } \\
0 . \text { no }\end{array}$ & $\frac{9^{2 * * *}}{65.1}$ & 0.000 & 6 & 1305 \\
\hline Able to prepare for exams & $\begin{array}{l}\text { 1. yes } \\
0 . \text { no }\end{array}$ & $\frac{93.2^{* * *}}{67.8}$ & 0.000 & 6.6 & 1305 \\
\hline
\end{tabular}

Chi -square tests. The underlined figures indicate that the percentage in the given cell is higher than expected in a random distribution. Level of significance: ${ }^{* * *} \mathrm{p}=0.000$. Source: HERD 2012 (subsample of Romania).

Table 8. Academic involvement of students and their intention on finishing the study (\%)

\begin{tabular}{cccccc}
\hline & & Intention & $\begin{array}{c}\text { Pearson } \\
\text { Chi-square }\end{array}$ & $\begin{array}{c}\text { Odds } \\
\text { ratio }\end{array}$ & $\mathbf{N}$ \\
\hline $\begin{array}{c}\text { Able to spend time studying instead of } \\
\text { doing more interesting things }\end{array}$ & $\begin{array}{c}\text { yes } \\
\text { no }\end{array}$ & $\begin{array}{c}\underline{\mathbf{8 9 . 8}}^{* * *} \\
\mathbf{7 1 . 3}\end{array}$ & 0.000 & 3.6 & 323 \\
Submits assignments in time & yes & $\mathbf{9 1 . 8 ^ { * * * }}$ & 0.000 & 6.2 & 323 \\
Makes every effort to be able to & no & 64.1 & & 7.6 & 323 \\
participate in courses & yes & $\mathbf{9 0 * * *}$ & 0.000 & & \\
Able to prepare for exams & yes & $\mathbf{8 9 * * *}$ & 0.000 & 4 & 323 \\
\hline
\end{tabular}

Chi -square tests. The underlined figures indicate that the percentage in the given cell is higher than expected in a random distribution. Level of significance: ${ }^{* * *} p=0.000$. Source: IESA 2014-2015 (subsample of Romania)

\section{References}

1. ANASOR . (2012). Impelementarea Procesului Bologna in Romania. Perspectiva studentilor. Alianța Națională a Organizațiilor Studențești din Romania.

2. Barro, R. J., \& Jong, W. L. (2013). A new data set of educational attainment in the word, 1950-2010. Journal of Development Economics, 104, 184-198.

3. Berei, E. B. (2018a). How do Students Perceive their Non-Traditional Peers at Romanian and Hungarian Universities? Hungarian Educational Research Journal, 8(2), 111-122.

4. Berei, E. B. (2018b). Krónikus betegség a felsőoktatásban? Lemorzsolódás-kockázat hátrányos helyzetű hallgatók körében. In G. Pusztai, \& F. Szigeti (Eds.), Lemorzsolódás és perzistencia a felsőoktatásban (pp. 284298). Debrecen: Debreceni Egyetemi Kiadó.

5. Bourdieu, P. (1978). A társadalmi egyenlőtlenségek újratermelődése. Budapest: Gondolat.

6. Boudon, R. (1981). The logic of social action. In G. Halász, \& J. Lannert (Eds.), Oktatási rendszerek elmélete (T. Bartus, Trans., pp. 406-417). Okker Kiadó. 
7. Brock, T. (2010). Young adults and higher education: barries and breackthroughts to success. Spring, 20(1), $109-132$.

8. Curaj, A. at al. (2015). Romanian Higher Education in 2009 - 2013. The Bologna Process and Romanian Priorities in the Search for an Active European and Global Presence. In A. Curaj at al. (Eds.), Higher Education Reforms in Romania. Between the Bologna Process and National Challenges (pp. 1-24). Springer Cham Heidelberg New York Dordrecht London: Springer.

9. ESIB - The national Unions of Students in Europe. (2007). Bologna with student eyes. London, UK: Bologna Process Committee 2005-2007.

10. ESU - The European Students'Union . (2012). Bologna with student eyes. Brussels: ESU .

11. Hatos, A. (2012). Enrollment in Higher Education: College Choice in the Hungarian - Romanian Cross Border Region. In G. Pusztai at al. (Eds.), Third Mission of Higher Education in a Cross - Border Region (pp. 179-198). University of Debrecen: CHERD - Hungary (Center for Higher Education Research and Development - Hungary).

12. Kozma, T. (2010). Expanzió. Expansion. Educatio 2010, 1, 7-18.

13. Polónyi, I. (2008). Oktatás, oktatáspolitika, oktatásgazdaság. Budapest: Nemzeti Tankönyvkiadó.

14. Pusztai, G. at al. (Eds.). (2012). Third mission of higher education in a cross-border region.

15. Pusztai, G. (2015). Pathways to success in higher education. Frankfurt am Main: Peter Lang Verlag.

16. Pusztai, G. at al. (Eds.). (2016). A felsőoktatás (hozzáadott) értéke. Közelítések az intézményi hozzájárulás empirikus megragadásához. Nagyvárad - Budapest: Partium - P.P.S-Ú.M.K.

17. Pusztai, G. (2016). Az intézményi hatás és forrásai. In G. Pusztai at al. (Eds.), A felsôoktatás (hozzáadott érték): közelitések az intézményi hozzájárulás empirikus megragadásához (pp. 112-137). Nagyvárad-Budapest: PPS, Új Mandátum.

18. Stanciu, S. (2014). A European Perspective on the Higher Education in Romania. American Journal of Educational Research, 2(7), 526-532.

19. Tinto, V. (1993). Leaving college. Rethinking the causes ad cures of student attrition. Chicago-London: University of Chicago Press.

20. Trow, M. (2005). Reflection on the transition from elite to mass universal access: forms and phases of higher education in modern societies since WWII. In P. A. ed., International Handbook of Higher Education. Kluwer.

(C) 2019 by the authors. Submitted for possible open access publication under the terms and conditions of the Creative Commons Attribution (CC BY) license (http://creativecommons.org/licenses/by/4.0/). 